\title{
Proposal for a universal measurement system for school chairs and desks for children from 6 to 10 years old
}

\author{
Vitor Carneiro ${ }^{\mathrm{a}, ~ *}$, Ângela Gomes ${ }^{\mathrm{a}}$, Bárbara Rangel ${ }^{\mathrm{b}}$ \\ ${ }^{a}$ Faculdade de Engenharia da Universidade do Porto, Rua Doutor Roberto Frias s/n, 4200-465, Porto, Portugal \\ ${ }^{\mathrm{b}}$ DESIGNSTUDIO, Faculdade de Engenharia da Universidade do Porto, Rua Doutor Roberto Frias s/n, 4200-465, Porto, Portugal
}

\section{A R T I C L E I N F O}

\section{Article history:}

Received 13 July 2015

Received in revised form

29 June 2016

Accepted 30 June 2016

Available online 8 August 2016

\section{Keywords:}

School furniture

Universal measurement system

Children

\begin{abstract}
A B S T R A C T
In a primary education classroom of any country, children of the same age have very different statures, reaching variations of $200 \mathrm{~mm}$ (Gonçalves, 2012). However, the school furniture provided is not suitable or adaptable to these differences. Designing school furniture able to respond to these variations is, therefore, a challenge for ergonomics and design in a global market. It is clearly not viable for industries to adapt productions for each country. When competitiveness and limitation of resources are essential for the viability of any product it becomes essential to find a universal system adapted to the requisites of any country.

Taking as prescription measure the popliteal height obtained from the data of different countries, a universal measurement system for the school chair and desk set is proposed, combining the ellipse methodology used by Molenbroek et al. (2003) and the (mis)match equations mentioned by Castellucci et al. (2014b).

From the results obtained, it can be concluded that only 5 sizes are needed to implement this new measurement system of evolutionary school furniture for the primary education classroom.
\end{abstract}

() 2016 Elsevier Ltd. All rights reserved.

\section{Introduction}

Growth is defined as the measurable physical changes of the body (Newman and Newman, 2012) that occur from birth to around 18-23 years old (Gonçalves, 2012; Ribeiro, 2012). Although growth depends on genetic potential, its pace and quality can, at any point, be disturbed by extrinsic factors (Ministério da Saúde do Brasil, 2002), such as bad posture during school years.

The constraints related to a sitting posture are considered more harmful for the human body than standing, therefore the design of the furniture used has a significant influence. Poorly designed school furniture may lead to bad posture habits which may have a direct impact on the growth process because they are likely to remain unchanged into adolescence or adulthood (Gonçalves, 2012; Gouvali and Boudolos, 2006; Panagiotopoulou et al., 2004; Parcells et al., 1999). Accordingly with Molenbroek et al. (2003) and Parcells et al. (1999) bad posture may lead to back, leg, arm, neck, shoulder and feet pain in school age children.

\footnotetext{
* Corresponding author. Address: Rua S. Tiago №46, 4590-064, Carvalhosa PFR, Porto, Portugal.
}

E-mail address: vitorcarneiro10@hotmail.com (V. Carneiro).
There are however contradictions about the direct relationship between poor posture and ergonomic school furniture. Troussier (1999) concludes that there is no modification of back pain prevalence in 8-11 year old schoolchildren using ergonomically designed furniture.

Despite these contradictory findings between studies and in a prevention perspective we considered important to take account of the hypothesis described by Molenbroek et al. (2003) and Parcells et al. (1999).

Chairs are the largest contributors to incorrect posture among children because they are not appropriate for the anthropometric and biomechanical characteristics of their users. Despite the fact that stature differences at the same age can reach $200 \mathrm{~mm}$, it is nonetheless common to use the same seat size for all students in the same class.

School furniture along with good posture training could address this issue. The primary goal of school furniture, in particular chairs and desks, is to promote comfort and good posture and thus enhance school performance (Castellucci et al., 2014b; Domljan et al., 2010; Gonçalves, 2012; Guat-Lin, 1984; Moro, 2005; Parcells et al., 1999). In their consideration of child anthropometry, many authors (Castellucci et al., 2015; Gonçalves, 2012; Molenbroek et al. 
2003; Panagiotopoulou et al., 2004; Parcells et al., 1999) have commented that school furniture should be adapted to the anthropometric changes that take place during growth.

The design of school furniture is guided by national and regularity standards. The countries in the European Union follow the Normative EN 1729-1, while in Brazil the NBR-14006 and NBR 14007 (Reis, 2003; Reis et al., 2005), and in the USA the ISO 5970 (Poston, 2002). Unfortunately, these standards do not always comply with the anthropometric reality of the users. For example, Gonçalves (2012) and Molenbroek et al. (2003) show that the European Standard does not fit the anthropometric reality of European children, demonstrating sizing gaps. For its part, Reis et al. (2005) shows that the Brazilian Standard is not fully implemented in terms of its practical application, revealing that Brazilian schools only use a single size of chairs and school desks for 7-17 years old leading to inadequate postures and musculoskeletal pathologies. Parcells et al. (1999) concludes that the furniture used in some North American schools is unsuitable with less than $20 \%$ of the students having a chair and desk compatible with their anthropometric dimensions. It can be seen, therefore, that there is a poor relationship between the actual anthropometric measures of each country and the dimensioning considered by their particular standards.

As demonstrated in the studies of Castellucci et al. (2015), Molenbroek et al. (2003), Gouvali and Boudolos (2006), among others, the anthropometric measures are directly related to the dimensions of the chair and desk. When the (mis)match equations are applied it is possible to obtain the optimal values for the considered sample.

Given the need of global manufacturing and the inherent diversity in the global market, it becomes a priority to develop an adaptable chair and desk for primary school children. A methodology of sizing, able to support the design of this adaptable chair and desk set and having as a prescribed criteria the popliteal height (PH), as advocated by Molenbroek et al. (2003) and Castellucci et al. (2015), which when compared with stature presents a "better $\mathrm{cu}$ mulative fit or match".

This methodology can be an important instrument to justify the designer's decision during the conceptual and development phases. An adjustable chair can be adapted to children with different statures from different countries. For the industry this is a very convenient solution, with one chair is possible to respond to the needs of different markets, enhancing responsiveness in production efficiency, environmental impact, market management and economic sustainability of the product.

\section{Material and methods}

The criteria of age selection in this study, between 6 and 10 years old, correspond to the school ages according to ISCED 1 - International Standard Classification of Education 2011 (UNESCO, 2012). The popliteal height $(\mathrm{PH})$ was taken as prescription criteria for the selection of the proper size of the chair and desk, as recommended by Molenbroek et al. (2003) and Castellucci et al. (2015). The (mis) match equations presented by Castellucci et al. (2014b) were taken in to account for sizing the universal chair.

The application of the equations requires anthropometric data. Therefore, anthropometric data/studies published in different counties addressing the anthropometric measures necessary for the sizing of the chair and desk set were taken into consideration.

The ellipses method of Molenbroek et al. (2003) was applied to the anthropometric data/studies, in order to determine how many sizes were required to cover the considered sample. From the number of sizes obtained, and depending on the other anthropometric data, the anthropometric values within the limits defined by the 5th and 95th percentiles of each size were achieved. Applying the values of the obtained limits from the selected (mis)match equations, the optimal values for the universal system of chair and school desk size for children from 6 to 10 years old were established.

\subsection{Sample}

With reference to the International Standard Classification of Education 2011 (UNESCO, 2012) it is in ISCED 1, primary school, that children have their first contact with school (Eurydice, 2014). Although there are some national variations. Attendance in primary schools generally starts between 5 and 7 years, with an average of 6 years old, and its duration is rarely less than 4 years. From this analysis it was decided to consider ages between 6 and 10 years old for the sample (Table 1 ).

\subsection{The popliteal height as a prescription measure}

Currently, most school furniture standards suggest stature as the prescription measure, taking as the basis the Pearson Correlation Coefficient (Castellucci et al., 2015). This coefficient shows that there is a strong positive correlation between stature and the other anthropometric variables, enabling a constant relationship to be established between the various segments of the body and stature through ratios (Guat-Lin, 1984). However, authors such as Molenbroek et al. (2003) and Castellucci et al. (2015) consider that this is not the most reliable criteria. Molenbroek et al. (2003) shows that when stature is used as the prescript criteria there may be ambiguity in the choice of size. For instances, the same stature can correspond to more than one size and, as a consequence, a higher chair can be chosen for children with a low popliteal height (PH). This happens because individuals with the same stature may have a range of different popliteal heights (PH) (Fig. 1). As Panero and Zelnik (1996) explain, the many anthropometric dimensions of an individual correspond to different percentiles.

Castellucci et al. (2015) shows that the popliteal height (PH), when compared with stature, is more precise and as such is the most appropriate anthropometric measure for the selection of the furniture's size. It is important to note that the starting point for the sizing of the chair and desk set is the seat height (SH) (Castellucci et al., 2010a, 2015; Molenbroek et al., 2003) and the seat height (SH) is defined by the popliteal height (PH) (Fig. 2).

Although, in schools, unlike stature, the knowledge about the measurement of the popliteal height is absent (Molenbroek et al., 2003). However, as shown by Castellucci et al. (2015), its measurement is not more difficult and/or time-consuming than stature when using simple strategies such as 'Peter lower leg meter', therefore their meaning is easily understood. Such simple measurement techniques can prevent incorrect choices of size. Molenbroek et al. (2003) also recommends the measurement of the popliteal height (PH), at least twice during a school year.

\section{3. (mis)Match equations and respective sizing criteria}

To design a system of measurements for school furniture the adoption of ergonomic criteria is necessary. In this development process, the dimensions of the furniture are related to the anthropometric dimensions of children, taking into account the (mis)match equations. This happens because, for example, the seat depth (SD) is based on the buttock-popliteal length (BPL), but if the seat depth (SD) corresponds to the exact measures of this anthropometric dimension a compression will occur on the back of the knee making the blood circulation in the legs and feet difficult (Gonçalves, 2012; Parcells et al., 1999; Reis, 2003) (Fig. 3). 
Table 1

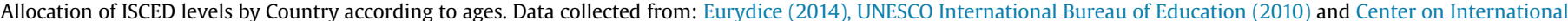
Education Benchmarking (2014).

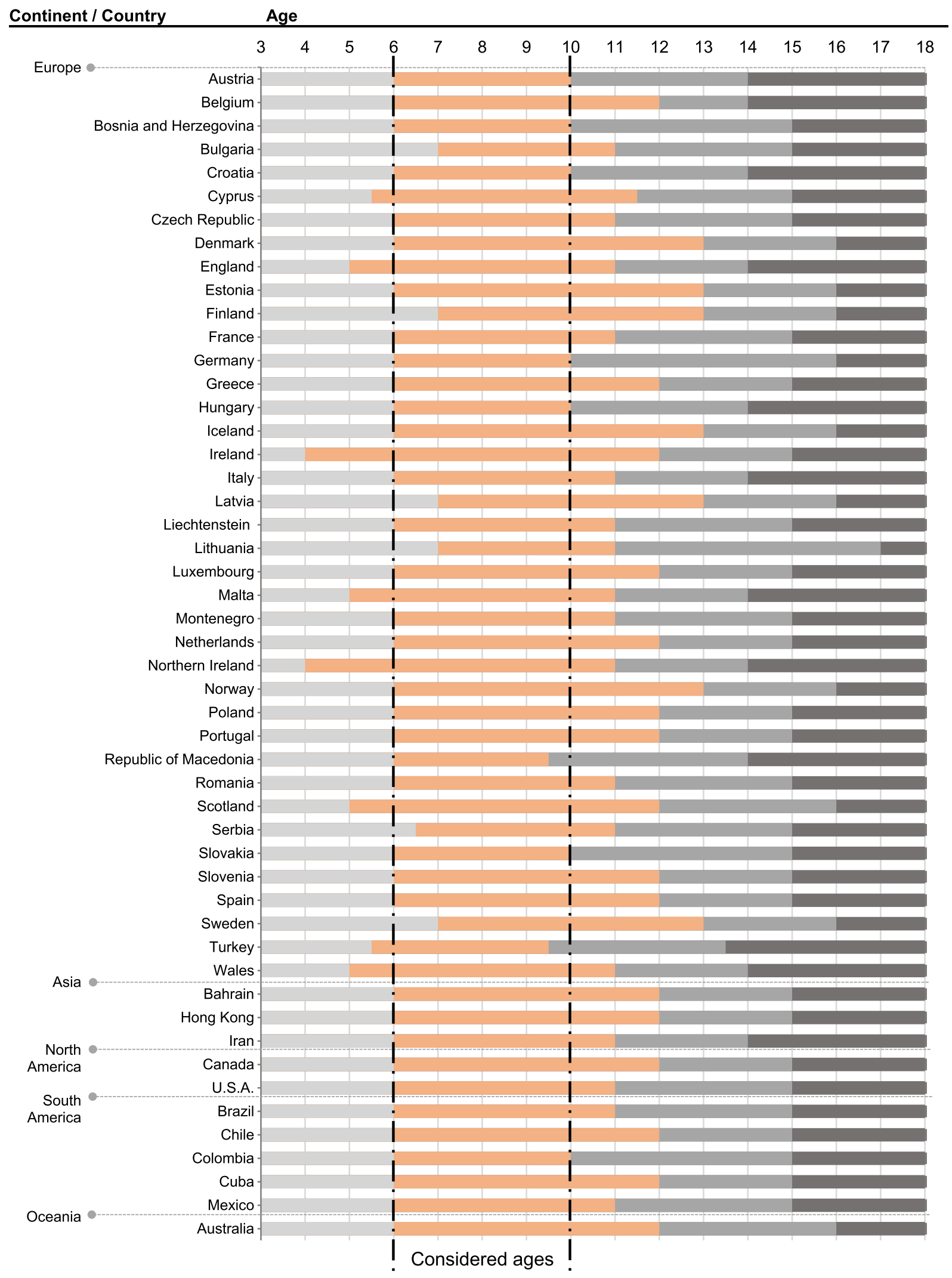




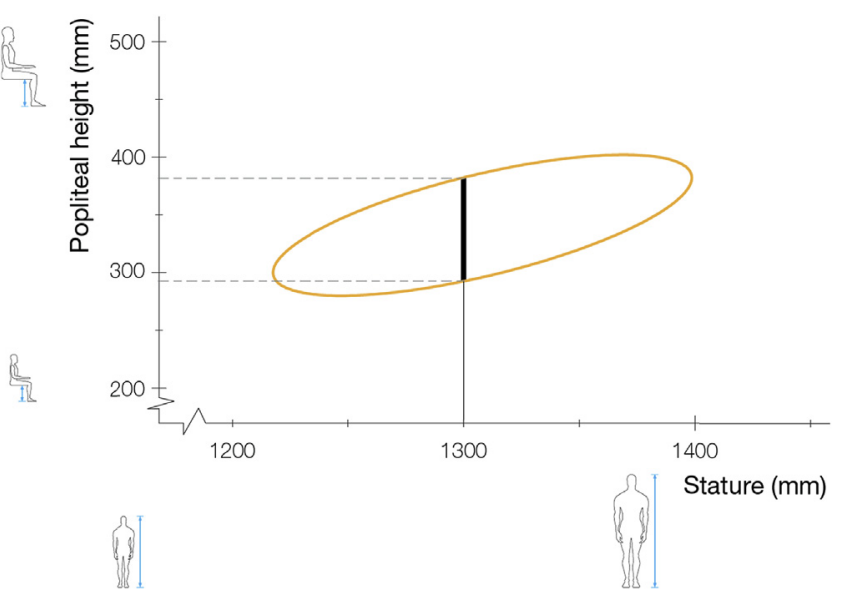

Fig. 1. In the anthropometric study conducted by Gonçalves (2012), at Portuguese children from 6 to 10 years old, it is observed that for a stature of $1300 \mathrm{~mm}$ corresponds to a popliteal height $(\mathrm{PH})$ range between approximately 300 and $400 \mathrm{~mm}$.

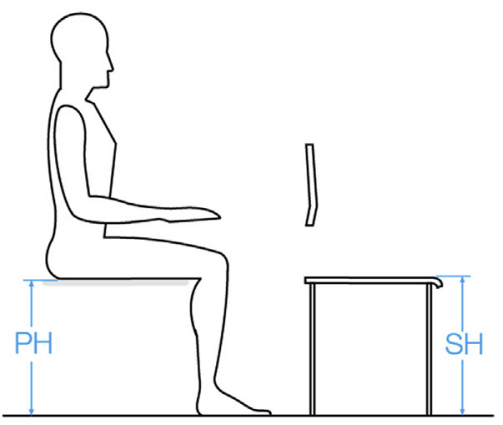

Fig. 2. Popliteal height $(\mathrm{PH})$ relates to seat height $(\mathrm{SH})$.
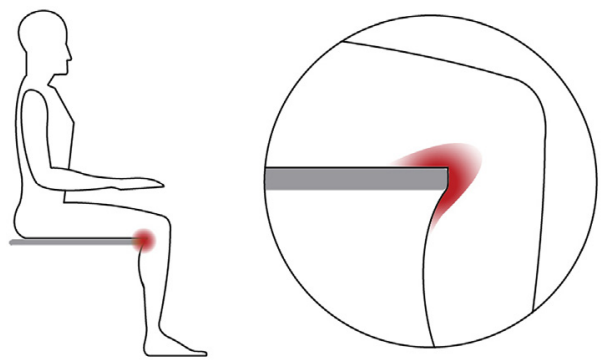

Fig. 3. A seat depth (SD) equal to the buttock-popliteal length (BPL) will originate a compression on the back of the knee making the blood circulation in the legs and feet difficult.
To apply anthropometric data in these equations is necessary to take into account the reference percentiles (Castellucci et al., 2014a; Molenbroek et al., 2003). As Moraes defends in her work of 1983 (quoted in Pequini, 2005), a product must adapt to the dimensional characteristics of at least $90 \%$ of the users, in other words, the people whose dimension vary between the percentile 5 and 95. For this reason these are considered as reference percentiles. The P5 will determine the dimension of the product that is defined by the lowest user, the seat height ( $\mathrm{SH}$ ) for example, and the P95 defines the dimensions of the product that are defined by the highest user, the seat width (SW) for example.

For the sizing of the chair and desk it is then necessary to consider the anthropometric measurement, the appropriate percentile and the corresponding (mis)match equation. The relevant anthropometric measures for the chair are popliteal height (PH), buttock-popliteal length (BPL), hip width (HW), subscapular height (SUH) or shoulder height sitting (SHS), height of lumbar point (HLP) and buttock clearance (BC). These will, respectively, obtain the seat height (SH), seat depth (SD), seat width (SW), upper edge of backrest (UEB), S point (SP) and lower edge of backrest (LEB). For the desk, the thigh thickness (TT) is considered to obtain the seat to desk clearance (SDC) (Fig. 4).

To articulate these dimensions the (mis)match equations used appear in two forms. Equations of one-way, in which only a minimum or maximum limit is considered. Equations of two-ways in which the minimum and maximum limits are taken into account (Castellucci et al., 2010a). Of the various (mis)match equations available in the literature and analysed by Castellucci et al. (2014b) the ones considered to be the most efficient for chair and desk sizing were considered (Table 2).

\subsubsection{Equation (1) - Seat height (SH)}

The seat height $(\mathrm{SH})$ is the starting point to dimension the chair and desk set (Castellucci et al., 2015). To obtain the seat height (SH) the Equation (1) (Afzan et al., 2012; Agha, 2010; Castellucci et al., 2010a; Dianat et al., 2013; Gouvali and Boudolos, 2006) was used. It is the only one that considers the biomechanics of the knee and considers that the inferior part of the leg makes an angle of 5-30 in relation to the vertical. This equation also considers the shoe correction (SC), which corresponds to the thickness of the sole of the shoe, that is added to the popliteal height $(\mathrm{PH})$, and can vary according to the culture, fashion and country (many authors report variations in the order of $20 \mathrm{~mm}, 25 \mathrm{~mm}-45 \mathrm{~mm}$ ) (Castellucci et al., 2015; Pheasant, 2003). This variable is especially important since the anthropometric measures are collected without the use of footwear (Castellucci et al., 2010b; Gonçalves, 2012; Gouvali and Boudolos, 2006; Parcells et al., 1999; Pheasant, 2003; Prado-León et al., 2001). For the purpose of this study, and because it is aimed at children, the shoe correction (SC) of $20 \mathrm{~mm}$ was

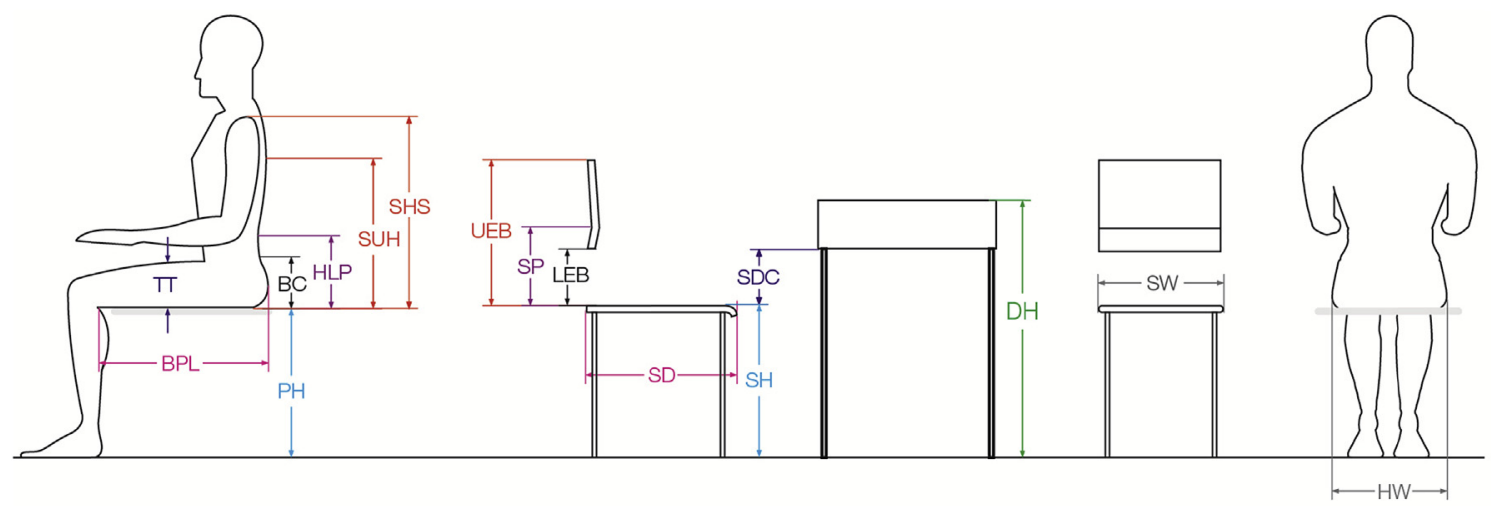

Fig. 4. Relevant anthropometric variables for school furniture sizing and its correlation with the product dimensions. 
Table 2

Summary table of the chair and table set dimensions through the (mis)match equations having as reference the anthropometric variable and percentiles.

\begin{tabular}{|c|c|c|c|c|c|c|}
\hline \multirow[b]{2}{*}{ Chair } & \multicolumn{2}{|c|}{ Anthropometric variable } & \multirow{2}{*}{$\begin{array}{l}\text { Reference percentile } \\
\text { P5 }\end{array}$} & \multirow{2}{*}{$\frac{\text { (mis)Match equations }}{\left.\left(\mathrm{PH}+\mathrm{SC}^{\mathrm{b}}\right) \cos 30^{\circ} \leq \mathrm{SH} \leq \mathrm{PH}+\mathrm{SC}\right) \cos 5^{\circ}(1)}$} & \multicolumn{2}{|c|}{ Relevant product dimension } \\
\hline & $\mathrm{PH}$ & Popliteal height & & & $\mathrm{SH}$ & Seat height \\
\hline & BPL & Buttock-popliteal length & P5 & $0.80 \mathrm{BPL} \leq \mathrm{SD} \leq .95 \mathrm{BPL}(2)$ & SD & Seat depth \\
\hline & HW & Hip width & P95 & $\mathrm{HW}<\mathrm{SW}(3)$ & SW & Seat width \\
\hline & SUH & $\begin{array}{l}\text { Subscapular height } \\
\text { Or }\end{array}$ & P5 & $\mathrm{SUH} \geq \mathrm{UEB}(4)$ & UEB & Upper edge of backrest \\
\hline & SHS & Shoulder height sitting & & 0,60 SHS $\leq$ UEB $\leq .80$ SHS (5) & & \\
\hline & HLP & Height of lumbar point & $\mathrm{P} 50^{\mathrm{a}}$ & $\simeq$ Navel height; $\simeq .5 \%$ stature $(6)$ & SP & S point \\
\hline & $\mathrm{BC}$ & Buttock clearance & P95 & $\simeq$ Iliac crest height; $\simeq 8 \%$ stature $(7)$ & LEB & Lower edge of backrest \\
\hline \multirow[t]{2}{*}{ Desk } & TT & Thigh thickness & P95 & $\mathrm{TT}+20 \mathrm{~mm}<\mathrm{SDC}(8)$ & SDC & Seat to desk clearance \\
\hline & & & & $\mathrm{SH}+\mathrm{SDC}+\mathrm{T}^{\mathrm{c}}(9)$ & $\mathrm{DH}$ & Desk height \\
\hline
\end{tabular}

a According to Molenbroek et al. (2003).

b Shoe correction.

c Table thickness.

considered.

The equation shows that the seat height $(\mathrm{SH})$ has to be bigger than $\cos 30^{\circ}$ of the popliteal height $(\mathrm{PH})$ added the shoe correction ( $\mathrm{SH})$ to avoid lower leg extension bigger than $30^{\circ}$ in relation to the vertical in the knee joint. This step is very important because with a larger extension, the soles of the feet would not be placed on the floor nor would the thighs have sufficient support, causing discomfort. On the other hand, the seat height $(\mathrm{SH})$ must be less than $\cos 5^{\circ}$ of the popliteal height (PH) plus the shoe correction (SC) to ensure that the students get both feet supported on the floor, without compressing the buttock region (Castellucci et al., 2014b, 2015; Molenbroek et al., 2003) (see Fig. 5).

\subsubsection{Equation (2) - Seat depth (SD)}

There are two equations to define seat depth (SD) presented in the literature. The difference between them is the maximum limit value of the buttock-popliteal length (BPL) considered. According to Castellucci et al. (2014b), if we opt for the alternative to Equation (2), that considers a bigger maximum limit, the space between the back of the knee and the seat will be clearly less. The author demonstrates that this gap would be a mere 3-6 mm based on the study of anthropometric measurements of Chilean children from 6 to 18 years old. Therefore, it was decided to use the Equation (2) (Afzan et al., 2012; Agha, 2010; Castellucci et al., 2010a; Dianat et al., 2013; Panagiotopoulou et al., 2004; Parcells et al., 1999) (see Fig. 6).

\subsubsection{Equation (3) - Seat width $(S W)$}

For the seat width (SW) it is used the Equation (3) (Afzan et al., 2012; Castellucci et al., 2010a). Since the school chair is not configured with armrest (Castellucci et al., 2014b), this is the only equation that takes this into account this aspect (see Fig. 7).

\subsubsection{Equation (4) and Equation (5) - Upper edge of backrest} (UEB)

According to the literature, the upper edge of the backrest (UEB) should preferably be below the subscapular, or on the limit of the subscapular line. Therefore, for the sizing of the upper edge of the backrest (UEB), the Equation (4) is used (Castellucci et al., 2010a) because it directly makes use of the subscapular height (SUH).

However, the anthropometric studies do not always present the subscapular height (SUH). Only in such cases, should Equation (5) be used (Afzan et al., 2012; Agha, 2010; Dianat et al., 2013; Gouvali and Boudolos, 2006), that considers the shoulder height sitting (SHS). This way, the choice of the equation to apply depends on the anthropometric data/studies available (see Fig. 8).

\subsubsection{Equation (6) - S point (SP), and Equation (7) - Lower edge of} backrest (LEB)

To determine the $S$ point (SP) and the lower edge of the backrest (LEB), although they correspond to an anthropometric measure, namely the height of lumbar point (HLP) and the buttock clearance (BC) respectively, the literature does not present any specific equation (Castellucci et al., 2014b). The anthropometric studies undertaken and published rarely include the measurement of the height of lumbar point (HLP) and the buttock clearance (BC), given its difficult evaluation. They are confined to very specific points of

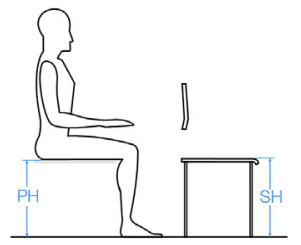

Seat height (SH)

$(\mathrm{PH}+\mathrm{SC}) \cos 30^{\circ} \leq \mathrm{SH} \leq(\mathrm{PH}+\mathrm{SC}) \cos 5^{\circ}(1)$

Fig. 5. Correlation between popliteal height $(\mathrm{PH})$ with seat height $(\mathrm{SH})$. Equation (1): Seat height $(\mathrm{SH})$ sizing.

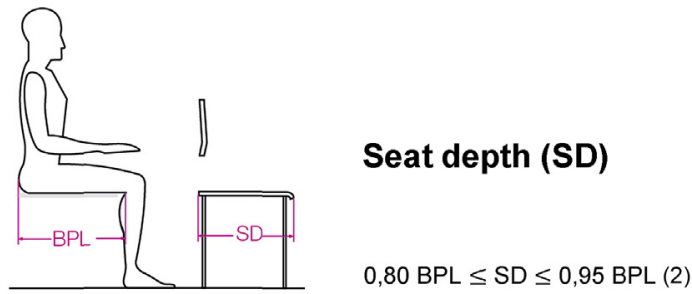

Fig. 6. Correlation between buttock-popliteal length (BPL) with seat depth (SD) Equation (2): Seat depth (SD) sizing.

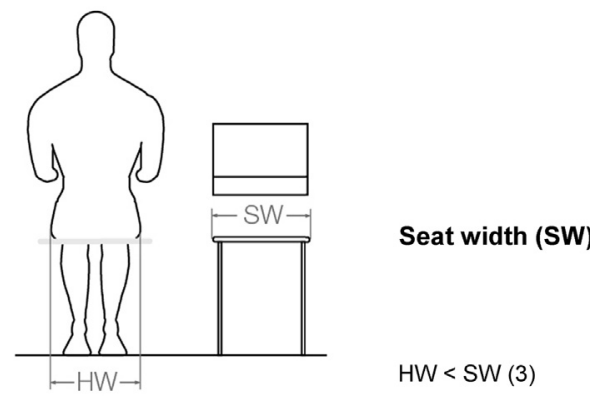

Fig. 7. Correlation between hip width (HW) with seat width (SW). Equation (3): Seat width (SW) sizing. 
the human body, which are difficult to evaluate visually and they do not present well-defined boundaries.

Since the time of Vitruvius, an almost linear relationship between the stature and the other anthropometric dimensions through ratios was established (Guat-Lin, 1984). Molenbroek et al. (2003) tell us that the dimension of the height of lumbar point (HLP) and the buttock clearance (BC) can be calculated through stature using Equation (6) and Equation (7) (see Figs. 9 and 10).

Although the application of this method is not entirely correct, since the anthropometric measurement collection should not be based on stature, it is the only way to obtain the values of the height of lumbar point (HLP) and the buttock clearance (BC). Given that the $S$ point (SP) and the lower edge of backrest (LEB) are important data for the sizing of the chair, and verifying that Molenbroek et al. (2003) used this method in their proposal for a system of European sizes for school furniture having the popliteal height $(\mathrm{PH})$ as selection criteria, it was opted to use this method.

\subsubsection{Equation (8) - Seat to desk clearance $(S D C)$}

To achieve this dimension it is possible to make use of the knee height or the thigh thickness (TT). It was considered the second criteria in the choice of the equation because, as noted by Castellucci et al. (2014b), the equations that use the knee height $(\mathrm{KH})$ "seem to be based in the erroneous assumption that $\mathrm{KH}$ is higher than the $\mathrm{SH}+\mathrm{TT}$ ".

Equation (8) (Castellucci et al., 2010a; Gouvali and Boudolos, 2006) was selected because it considers that the seat to desk

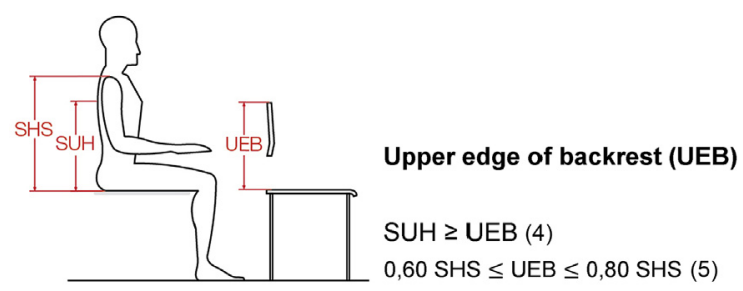

Fig. 8. Correlation between subscapular height (SUH) or shoulder height sitting (SHS) with upper edge of backrest (UEB). Equation (4): Upper edge of backrest (UEB) sizing through the subscapular height (SUH). Equation (5): Upper edge of backrest (UEB) sizing through the shoulder height sitting (SHS).

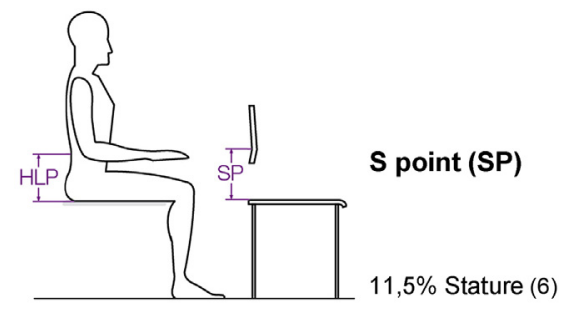

Fig. 9. Correlation between height of lumbar point (HLP) with S point (SP). Equation (6): S point (SP) sizing.

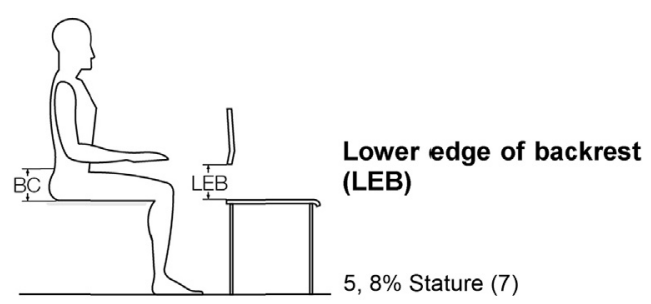

Fig. 10. Correlation between buttock clearance (BC) with lower edge of backrest (LEB). Equation (7): Lower edge of backrest (LEB) sizing.

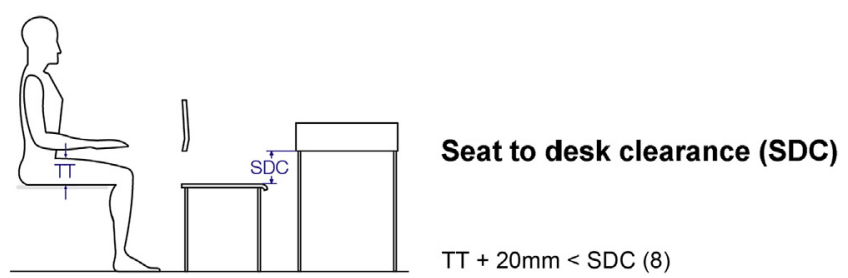

Fig. 11. Correlation between thigh thickness (TT) with seat to desk clearance (SDC). Equation (8): Seat to desk clearance (SDC) sizing.

clearance (SDC) should be related to thigh thickness (TT) with an added clearance of $20 \mathrm{~mm}$ at least (Iida, 2005; Molenbroek et al., 2003), to allow the individual to stand, sit and make postural changes (see Fig. 11).

\subsubsection{Equation (9) - Desk height (DH)}

To determine the desk height $(\mathrm{DH})$ the literature presents several equations based on ergonomic criteria, considering factors such as the anthropometric variable elbow height sitting and the biomechanics of the shoulder and elbow, but not taking into account the seat to desk clearance (SDC). According to Castellucci et al. (2014a) with the use of these criteria "[...] it is not possible to define a convincing equation or special criteria for DH." Because "[...] the interrelation between the criteria for $D H$ and SDC can be contradictory, even in ideal conditions."

As an alternative, the author proposes the Equation (9) that considers the seat height (SH), the seat to desk clearance (SDC) and the table thickness (T). Its formulation is justified, first, by the fact that the starting point of the sizing of the school furniture is the seat height (SH). Second, a large enough seat to desk clearance (SDC) space is needed to allow the individual to stand, to sit and make posture changes. Therefore, the Equation (8) is convenient to determine that specific space.

Finally, it is necessary to consider the table thickness (T). To attenuate the problem of individuals using a higher desk height (DH), the author recommends the use of low values for the table thickness (T). In the present study, a table thickness (T) of $65 \mathrm{~mm}$ was considered because usually the lids of school desk, on a particleboard, have a thickness of $22 \mathrm{~mm}$ and are fixed to structures with $40 \mathrm{~mm}$ (see Fig. 12).

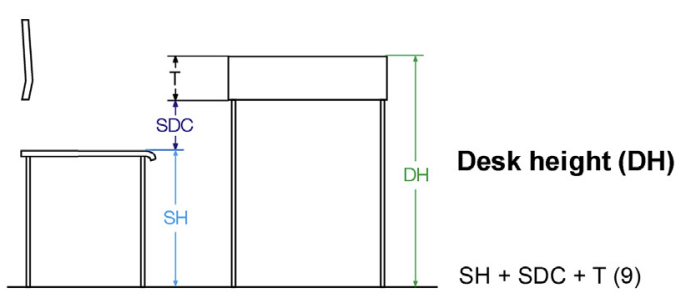

Fig. 12. Correlation between seat height (SH), seat to desk clearance (SDC) and table thickness (T) with desk height (DH). Equation (9): Desk height (DH) sizing.

\subsection{Anthropometric data/studies found and used}

In the development of the study for a universal system of measurements for school chairs and desks for children from 6 to 10 years old, the anthropometric data of children from many countries were considered. However, it was not possible to obtain a significant amount of anthropometric data from some countries. In some cases, anthropometric data for the age range in question was missing, or certain measurements, such as popliteal height $(\mathrm{PH})$ 
Table 3

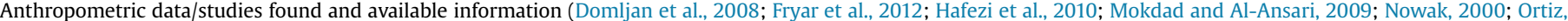
2008).

\begin{tabular}{|c|c|c|c|c|c|c|c|c|c|c|c|c|c|c|c|c|c|c|c|}
\hline \multirow[b]{2}{*}{$\begin{array}{l}\text { Anthropometric } \\
\text { Studies/Data }\end{array}$} & \multirow[b]{2}{*}{$\begin{array}{l}\text { Standard } \\
\text { Deviation }\end{array}$} & \multirow[b]{2}{*}{ Mean } & \multirow{2}{*}{$\left|\begin{array}{c}\text { Male } \\
+ \\
\text { Female }\end{array}\right|$} & \multicolumn{3}{|c|}{ Percentile } & \multicolumn{5}{|c|}{ Age } & \multicolumn{8}{|c|}{ Anthropometric Variable } \\
\hline & & & & 5 & 50 & 95 & 6 & 7 & 8 & 9 & 10 & Stature & $\begin{array}{c}\text { Popliteal } \\
\text { height }\end{array}$ & $\begin{array}{c}\text { Buttock- } \\
\text { popliteal } \\
\text { length }\end{array}$ & $\begin{array}{l}\text { Hip } \\
\text { width }\end{array}$ & $\begin{array}{c}\text { Thigh } \\
\text { thickness }\end{array}$ & \begin{tabular}{|c} 
Shoulder \\
height \\
sitting
\end{tabular} & $\begin{array}{c}\text { Subscapular } \\
\text { height }\end{array}$ & $\begin{array}{c}\text { Height of } \\
\text { lumbar } \\
\text { point }\end{array}$ \\
\hline $\begin{array}{l}\text { Portugal } \\
\text { Gonçalves (2012) }\end{array}$ & $\bullet$ & - & - & $\bullet$ & $\bullet$ & $\bullet$ & $\bullet$ & $\bullet$ & $\bullet$ & $\bullet$ & $\bullet$ & $\bullet$ & - & $\bullet$ & $\bullet$ & $\bullet$ & $\bullet$ & - & - \\
\hline $\begin{array}{l}\text { Netherlands } \\
\text { Steenbekkers et al. } \\
\text { (1993) }\end{array}$ & $\bullet$ & $\bullet$ & $\bullet$ & $\bullet$ & $\bullet$ & $\bullet$ & $\bullet$ & $\bullet$ & $\bullet$ & $\bullet$ & $\bullet$ & $\bullet$ & $\bullet$ & $\bullet$ & $\bullet$ & $\bullet$ & $\bullet$ & - & - \\
\hline $\begin{array}{l}\text { Belgium } \\
\text { Motmans and } \\
\text { Ceriez (2005) }\end{array}$ & $\bullet$ & $\bullet$ & $\bullet$ & $\bullet$ & $\bullet$ & $\bullet$ & $\bullet$ & $\bullet$ & $\bullet$ & $\bullet$ & $\bullet$ & $\bullet$ & $\bullet$ & $\bullet$ & - & $\bullet$ & $\bullet$ & - & - \\
\hline $\begin{array}{l}\text { Poland } \\
\text { Nowak (2000) }\end{array}$ & - & - & - & • & $\bullet$ & $\bullet$ & • & $\bullet$ & $\bullet$ & $\bullet$ & $\bullet$ & • & • & $\bullet$ & $\bullet$ & • & • & - & - \\
\hline $\begin{array}{l}\text { United } \\
\text { kingdom } \\
\text { Pheasant (2003) }\end{array}$ & $\bullet$ & - & - & $\bullet$ & $\bullet$ & $\bullet$ & $\bullet$ & $\bullet$ & $\bullet$ & $\bullet$ & $\bullet$ & $\bullet$ & $\bullet$ & $\bullet$ & $\bullet$ & $\bullet$ & $\bullet$ & - & - \\
\hline $\begin{array}{l}\text { Croatia } \\
\text { Domljan et al. } \\
(2008)\end{array}$ & $\bullet$ & $\bullet$ & $\bullet$ & - & - & - & - & $=$ & - & $=$ & $=$ & - & $\bullet$ & $\bullet$ & $\bullet$ & - & - & - & - \\
\hline $\begin{array}{l}\text { Chile } \\
\text { Castellucci et al. } \\
(2015)\end{array}$ & $\bullet$ & $\bullet$ & - & $\bullet$ & $\bullet$ & $\bullet$ & $\bullet$ & $\bullet$ & $\bullet$ & $\bullet$ & $\bullet$ & $\bullet$ & $\bullet$ & $\bullet$ & $\bullet$ & $\bullet$ & $\bullet$ & - & - \\
\hline $\begin{array}{l}\text { Brazil } \\
\text { Paschoarelli (1997) }\end{array}$ & • & $\bullet$ & • & • & $\bullet$ & • & $\bullet$ & $\bullet$ & - & - & - & $\bullet$ & • & • & - & - & • & - & - \\
\hline $\begin{array}{l}\text { Brazil } \\
\text { Silva et al. (1995) }\end{array}$ & $\bullet$ & • & $\bullet$ & • & $\bullet$ & $\bullet$ & - & $\bullet$ & $\bullet$ & $\bullet$ & $\bullet$ & $\bullet$ & • & • & $\bullet$ & $\bullet$ & $\bullet$ & $=$ & $=$ \\
\hline $\begin{array}{l}\text { Mexico } \\
\text { Prado-León et al. } \\
\text { (2001) }\end{array}$ & $\bullet$ & $\bullet$ & - & - & - & - & $\bullet$ & $\bullet$ & $\bullet$ & $\bullet$ & $\bullet$ & $\bullet$ & $\bullet$ & $\bullet$ & $\bullet$ & $\bullet$ & • & $\bullet$ & - \\
\hline $\begin{array}{l}\text { Cuba } \\
\text { Fuentes (2001) }\end{array}$ & • & $\bullet$ & - & • & $=$ & - & $\bullet$ & $\bullet$ & $\bullet$ & $\bullet$ & $\bullet$ & • & • & • & • & $\bullet$ & - & $\bullet$ & $\bullet$ \\
\hline $\begin{array}{l}\text { Colombia } \\
\text { Ortiz (2008) }\end{array}$ & - & $\bullet$ & - & $\bullet$ & - & • & $\bullet$ & $\bullet$ & $\bullet$ & $\bullet$ & $\bullet$ & • & • & • & • & • & • & - & - \\
\hline $\begin{array}{l}\text { U.S.A } \\
\text { Fryar et al. (2012) }\end{array}$ & $\bullet *$ & $\bullet$ & - & • & - & • & • & $\bullet$ & $\bullet$ & $\bullet$ & $\bullet$ & $\bullet$ & - & - & - & • & - & - & - \\
\hline $\begin{array}{l}\text { U.S.A } \\
\text { Malina et al. (1973) }\end{array}$ & $\bullet *$ & $\bullet$ & - & • & $\bullet$ & $\bullet$ & $\bullet$ & $\bullet$ & $\bullet$ & $\bullet$ & $\bullet$ & • & • & $\bullet$ & $\bullet$ & $\bullet$ & - & - & - \\
\hline $\begin{array}{l}\text { Canada } \\
\text { Canadian Institute } \\
\text { of Child Health } \\
(2007)\end{array}$ & $\bullet$ & $\bullet$ & $\bullet$ & • & - & $\bullet$ & $\bullet$ & $\bullet$ & $\bullet$ & $\bullet$ & $\bullet$ & $\bullet$ & $\bullet$ & • & $\bullet$ & - & - & - & - \\
\hline $\begin{array}{l}\text { Iran } \\
\text { Hafezi et al. (2010) }\end{array}$ & • & • & - & - & • & $\bullet$ & - & $\bullet$ & $\bullet$ & $\bullet$ & • & • & - & - & • & - & - & - & - \\
\hline $\begin{array}{l}\text { Hong Kong } \\
\text { Evans et al. (1988) }\end{array}$ & • & • & - & - & - & - & • & $\bullet$ & $\bullet$ & $\bullet$ & $\bullet$ & - & • & • & $\bullet$ & • & - & • & - \\
\hline $\begin{array}{l}\text { Bahrain } \\
\text { Mokdad and Al- } \\
\text { Ansari (2009) }\end{array}$ & $\bullet$ & $\bullet$ & - & - & - & - & $\bullet$ & $\bullet$ & $\bullet$ & $\bullet$ & $\bullet$ & • & - & $\bullet$ & $\bullet$ & - & - & - & - \\
\hline
\end{tabular}

Data not used for not presenting information about the popliteal height $(\mathrm{PH})$ and/or about the ages considered.

Data used after calculations to group male and

female gender in only one set.
Data not used because they are presented by school years

Data not used because it was not possible to join genders in only one set
Unused data for inconsistencies between the percentiles and standard deviation.

Data used without need for additional calculations.

- Yes - No •* The Standard Error of the Mean (SEM) is available making it possible the calculation of the Standard Deviation (SD)

had not been included. In the following table the countries from which it was possible to obtain the anthropometric data and what variables were available are presented (Table 3 ).

The countries indicated in red were excluded because relevant anthropometric data was missing, or it was hard to reconcile the data provided with the specific ages. The countries in yellow did not classify the data by age but rather by school years making it impossible to use. For example, the 4th school year In Portugal is typically frequented by children with 9-10 years old, but in certain circumstances children may be required to retake years, so may be older than the expected age. (Gonçalves, 2012).

In the countries in orange, the standard deviation (SD) and the percentiles do not correspond well, indicating potential problems with measuring systems or recording of data. According to Moraes, in her work in 1983 (quoted in Pequini, 2005), "the percentiles can be obtained arithmetically from the standard deviation, if the mean is known. The standard deviation is the measure of dispersion, variation or expansion towards a mean. Thus, the mean, (or percentile 50 of a normal curve) $[\ldots] \pm 2$ SD includes $95,4 \%$ of the group".

In these countries, when added the mean $(\mu)$ with 2SD the resulting value was very different from the one indicated in P95. For example, on the anthropometric study of children conducted by Canadian Institute of Child Health (2007), the mean ( $\mu$ ) popliteal height (PH) for 6 years old is $301,7 \mathrm{~mm}$, the standard deviation (SD) is $18,3 \mathrm{~mm}$ and the $\mathrm{P} 95$ indicated is $\mathbf{3 1 5 . 5} \mathbf{~ m m}$. However $301.7+2 \times 18,3=\mathbf{3 3 8 . 3} \mathbf{~ m m}$. As it can be seen there is a 
substantial difference.

In the countries indicated in dark blue, the anthropometric dimensions are individualized by gender. Since between 6 and 10 years old there is no growth rate difference between sexes (AAVV, 2013) the separation of data by gender would not make sense for this study. Therefore the standard deviation (SD) and the mean $(\mu)$ samples can be combined, using two equations (Motmans and Ceriez, 2005). With Equation (10) the standard deviation (SD) of the set is obtained and with Equation (11) the mean $(\mu)$ of the set.

$\mathrm{SD}_{\mathrm{A}+\mathrm{B}}^{2}=\% \mathrm{~A} \times \mathrm{SD}_{\mathrm{A}}^{2}+\% \mathrm{~B} \times \mathrm{SD}_{\mathrm{B}}^{2}+\% \mathrm{~A} \times \% \mathrm{~B} \times(\mu \mathrm{A}-\mu \mathrm{B})^{2}$

$\mu_{\mathrm{A}+\mathrm{B}}=\% \mathrm{~A} \times \mu_{\mathrm{A}}+\% \mathrm{~B} \times \mu_{\mathrm{B}}$

In which: $\mu$ - mean; SD - Standard deviation; A - sex a; B - sex b; $\%$ - percentage of the sample.

The calculations of the percentiles is obtained arithmetically from the standard deviation (SD) and the mean ( $\mu$ ) and each percentile corresponds a value from the Standard Normal Distribution (Z-value) table (Motmans and Ceriez, 2005; Pequini, 2005). The percentiles inferior to $\mathrm{P} 50$ have a negative Z-value and above P50 positive (Motmans and Ceriez, 2005) (Table 4).

With the Z-value and the standard deviation (SD) and the mean $(\mu)$ value of the set we can calculate the percentiles as indicates Equation (12).

$\mathrm{P}_{\mathrm{p}}=\mu+\mathrm{SD} \times \mathrm{Z}_{\mathrm{p}}$

In which: $z_{p}-$ constant for the percentile considered, obtained from the Standard Normal Distribution Table.

The countries indicated in light blue are in the same situation as the countries in dark blue: the anthropometric dimensions are individualized by gender. However they did not present the dimension of the sample, the standard deviation (SD) and/or the mean $(\mu)$ making it impossible to calculate the set through the Equation (10) and Equation (11) therefore being excluded. Finally, on the countries indicated in green the anthropometric variables were available, the intended percentiles and the data were not individualized by gender, so they were used directly in the study without the need for additional calculations.

From this analysis it was decided to use the anthropometric data from the countries presented on Table 5 with the following

Table 4

- Values of the Standard Normal Distribution table (Z-Value) and the corresponding percentile.

\begin{tabular}{llllll}
\hline & P1 & P5 & P50 & P95 & P99 \\
\hline Z-Value & -2.33 & -1.65 & 0 & 1.65 & 2.33 \\
\hline
\end{tabular}

Table 5

Anthropometric studies selected.

\begin{tabular}{lll}
\hline Country & Author(s) & Year of the study \\
\hline Portugal & Gonçalves (2012) & 2012 \\
Netherlands & Steenbekkers et al. (1993) & 1993 \\
Belgium & Motmans and Ceriez (2005) & 2005 \\
United Kingdom & Pheasant (2003) & 1986 \\
Chile & Castellucci et al. (2015) & 2010 \\
Brazil & Paschoarelli (1997) & 1995 \\
Brazil & Silva et al. (1995) & 1995 \\
Mexico & Prado-León et al. (2001) & 2001 \\
Cuba & Fuentes (2001) & 1977 \\
U.S.A. & Malina et al. (1973) & 1965 \\
Hong Kong & Evans et al. (1988) & 1982 \\
\hline
\end{tabular}

adjustments. The studies from Cuba and Hong Kong, only present the anthropometric variable subscapular height (SUH) therefore cannot be used only to define the upper edge of backrest (UEB). Both studies from Brazil, from the same year, complement each other and are therefore grouped into a single set. The fact that one of these studies does not have information on the anthropometric variable thigh thickness (TT) led to the non-use only on the sizing of the seat to desk clearance (SDC). Lastly, and although the anthropometric studies of Cuba from 1977 and the USA from 1965 may be invalidated given the secular trend of Human growth (Guat-Lin, 1984; Ministério da Saúde do Brasil, 2002), these were included because it was not possible to obtain more recent anthropometric data, or when they exist they did not possess the anthropometric variable popliteal height $(\mathrm{PH})$.

\section{Calculation}

The proposed methodology is based on two assumptions defined by Molenbroek et al. (2003) and Castellucci et al. (2015):

1. The sizes of the chair and desk set should be prescribed having as reference the popliteal height $(\mathrm{PH})$ instead of the stature. This can only serve as a secondary reference but never, in any case, as a primary reference running the risk of choosing the wrong size.

2. The starting point for the sizing of the chair and desk set is the seat height $(\mathrm{SH})$, this being defined by the popliteal height $(\mathrm{PH})$.

To determine the size system the (mis)match equations, mentioned above, were used combined with the ellipses method used by Molenbroek et al. (2003). In this method, scatter plots are estimated for the anthropometric data found of the different countries. Through the P5 and P95 data of the popliteal height (PH) (y axis) and the other anthropometric measurements (x-axis), necessary for the sizing of the chair and table set, are designed rectangles by age group. Finally, on these rectangles an ellipse for each population is drawn (Fig. 13).

Once the ellipses of each country are obtained, these are aggregated into single graphics according to its variables (Fig. 14).

As the prescribing measure is the popliteal height ( $\mathrm{PH})$, all charts have in common this dimension on the y axis. So, by using Equation (1), which takes into account the maximum and minimum comfortable popliteal height $(\mathrm{PH})$, the seat height $(\mathrm{SH})$

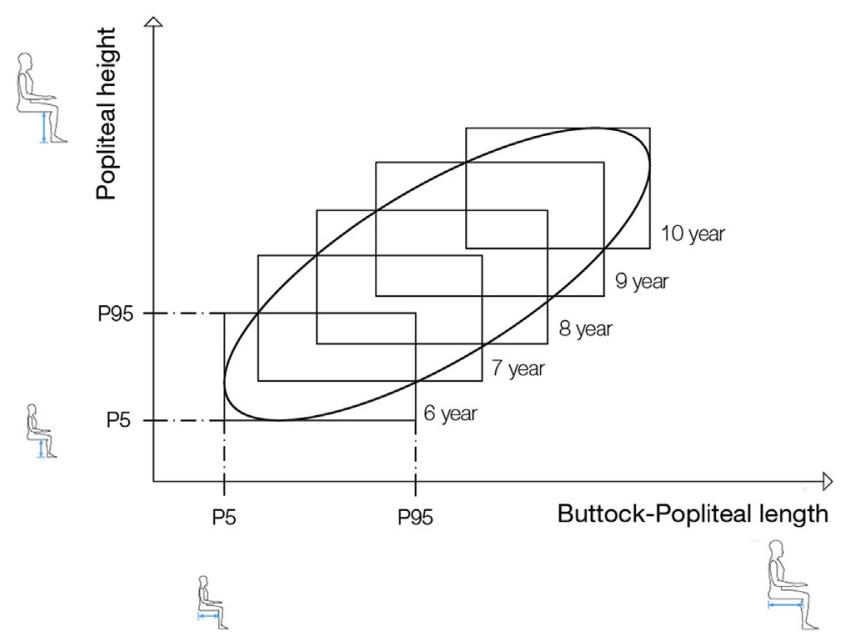

Fig. 13. - Example of a schematic representation of the estimated scatter plots of the popliteal height (PH) and buttock-popliteal length (BPL). Adapted from Molenbroek et al. (2003). 


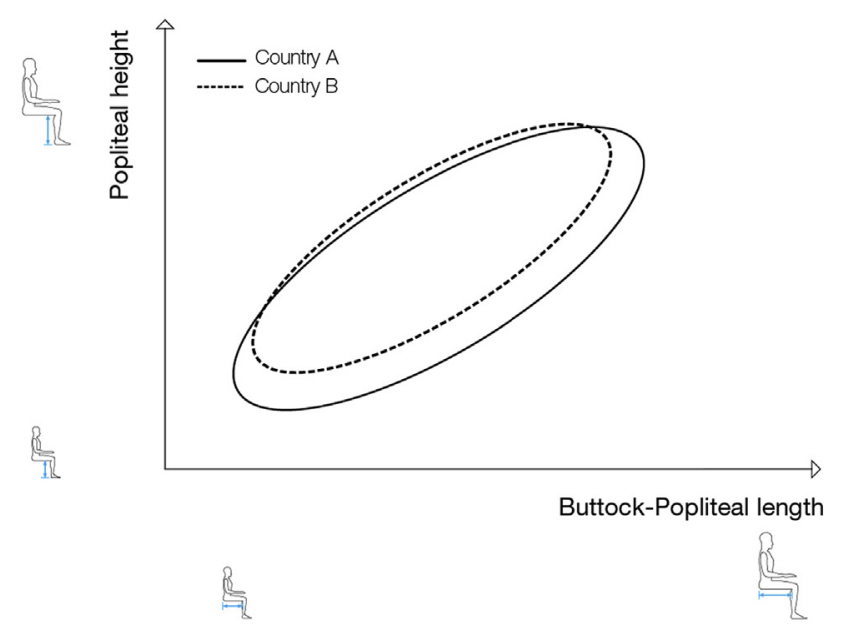

Fig. 14. Example of an aggregation of the ellipses of two countries in one graph according to the variables popliteal height (PH) and buttock-popliteal length (BPL).

required to properly accommodate all specifications is determined and, consequently, the number of sizes (Fig. 15).

From these sizes it is possible to determine the interval corresponding to the second anthropometric variable to obtain its maximum (P95) and minimum (P5) value for its later application in the correspondent equation. In Fig. 16, on size 1 point A represents the minimum comfortable height for the popliteal and the lower correspondent (P5) buttock-popliteal length (BPL) and point B represents the maximum comfortable height of the popliteal and the largest correspondent (P95) buttock-popliteal length (BPL). In this case, for the value of $A$, the lower buttock-popliteal length (BPL), is applied the Equation (2) to determine the seat depth for size 1 . The process is repeated for the following sizes.

Following this principle, the process is repeated for the remaining dimensions to find the optimal values of the chair and desk set.

\subsection{Calculation of the seat height (SH)}

The Equation (1) set for the calculation of the seat height ( $\mathrm{SH}$ ) has as a reference the popliteal height $(\mathrm{PH})$ plus the shoe correction (SC) and considering P5 as reference percentile.

For the calculation of these values, the Equation (1) was applied on the lower popliteal height (PH), P5, of the countries considered, obtaining the maximum and minimum value of the seat height $(\mathrm{SH})$

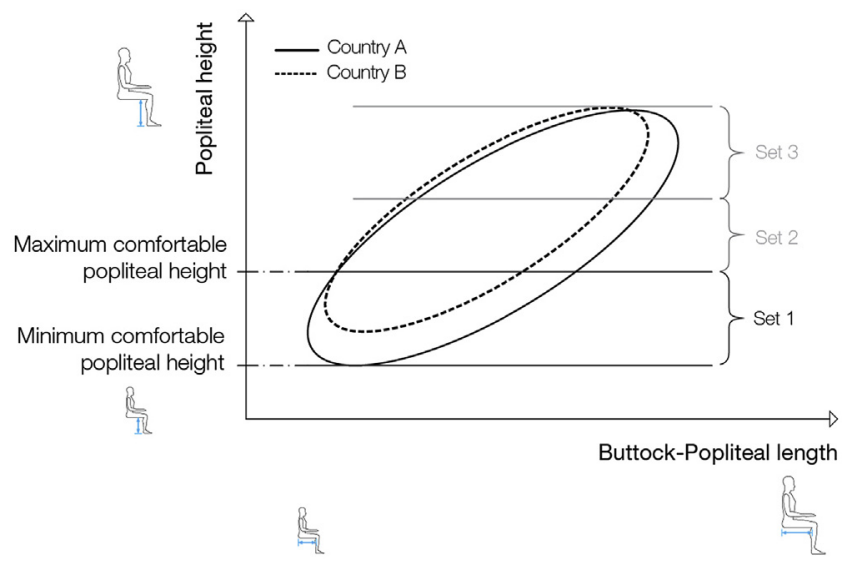

Fig. 15. Example of the determination of the seat heights $(\mathrm{SH})$ needed to properly accommodate all involved and consequently the number of sizes.

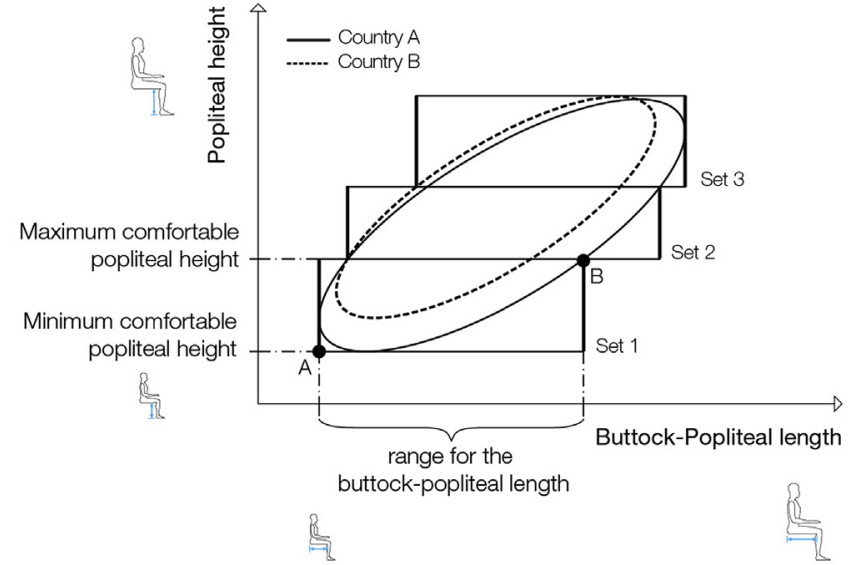

Fig. 16. - Schematic representation of 3 sizes over a bivariate distribution of popliteal height (PH) and buttock-popliteal length (GGP) correspondent ranges. Adapted from Molenbroek et al. (2003).

defining size 1 . For size 2 it is assumed that the maximum seat height $(\mathrm{SH})$ of size 1 corresponds to its minimum seat height $(\mathrm{SH})$ (Molenbroek et al., 2003). Knowing this seat height (SH) and using the maximum limit of Equation (1) inverted, the corresponding popliteal height $(\mathrm{PH})$ is calculated. Having determined the popliteal height $(\mathrm{PH})$, this is applied to the minimum limit of Equation (1) to calculate the maximum seat height $(\mathrm{SH})$ and thereby define size 2 (Table 6). The calculation is repeated until all the seat heights ( $\mathrm{SH})$ and necessary sizes have been established.

In Fig. 17, which relates the popliteal height $(\mathrm{PH})$ and stature, it is observed that 5 sizes (rectangles) are necessary to properly accommodate all children and that for a popliteal height (PH) corresponds only to one size, which no longer happens with the stature.

\subsection{Calculation of the seat depth (SD)}

The Equation (2) set for the calculation of the seat depth (SD) has as a reference the buttock-popliteal length (BPL) and P5 as reference percentile. To obtain these values, a graphic that relates the popliteal height (PH) and the buttock-popliteal length (BPL) was obtained. For each size the value of the percentile of reference (lower left corner of each rectangle) of the buttock-popliteal length (BPL) range is identified (Fig. 18).

The obtained values of P5, the Equation (2) are applied to achieve the optimal dimension of the seat depth (SD) on the 5 sizes proposed.

\subsection{Calculation of the seat width (SW)}

The Equation (3) has as a reference point the hip width (HW) and for this measure the maximum percentile (P95) is considered. The following ellipses chart presents the relation between the popliteal height $(\mathrm{PH})$ and the hip width (HW). In each size, the value of the reference percentile (top right corner of each rectangle) of the hip width (HW) range (Figs. 19) is identified.

Having obtained the P95 values of each size, the Equation (3) is applied to achieve the optimal dimension of the seat width (SW) on the 5 sizes proposed.

\subsection{Calculation of the upper edge of the backrest (UEB)}

Given the fact that almost all the anthropometric data/studies selected make available only the shoulder height sitting (SHS), the 
Table 6

Calculation of the seat height $(\mathrm{SH})$ for the sizes 1 and 2 .

\begin{tabular}{|c|c|c|c|c|c|}
\hline \multirow[b]{2}{*}{ Size } & \multirow{2}{*}{$\begin{array}{l}\text { Popliteal } \\
\text { height (PH) } \\
\text { P5 }\end{array}$} & \multicolumn{2}{|c|}{ Seat height (SH) } & \multirow{2}{*}{$\begin{array}{c}\text { Inverted maximum limit of } \\
\text { Equation (1) }\end{array}$} & \multirow{2}{*}{$\begin{array}{c}\text { Minimum limit of } \\
\text { Equation (1) }\end{array}$} \\
\hline & & Min & Max & & \\
\hline 1 & 237,0 & 222,6 & 256 & \multirow{2}{*}{$\mathrm{PH} \geq \frac{\mathrm{SH}}{\cos 30^{\circ}}-\mathrm{SC}$} & \multirow[t]{2}{*}{$\mathrm{SH} \leq\left(\mathrm{PH}_{1}+\mathrm{SC}\right) \cos 5^{\circ}$} \\
\hline 2 & $\mathrm{PH}_{1}$ & 256 & $\mathrm{SH}_{2}$ & & \\
\hline & & & & $\begin{aligned} \mathrm{AP}_{1} & \geq \frac{256}{\cos 30^{\circ}}-20 \\
& \geq 275,6\end{aligned}$ & $\begin{aligned} \mathrm{SH}_{2} & \leq(275,6+20) \cos 5^{\circ} \\
& \leq 294,5\end{aligned}$ \\
\hline
\end{tabular}

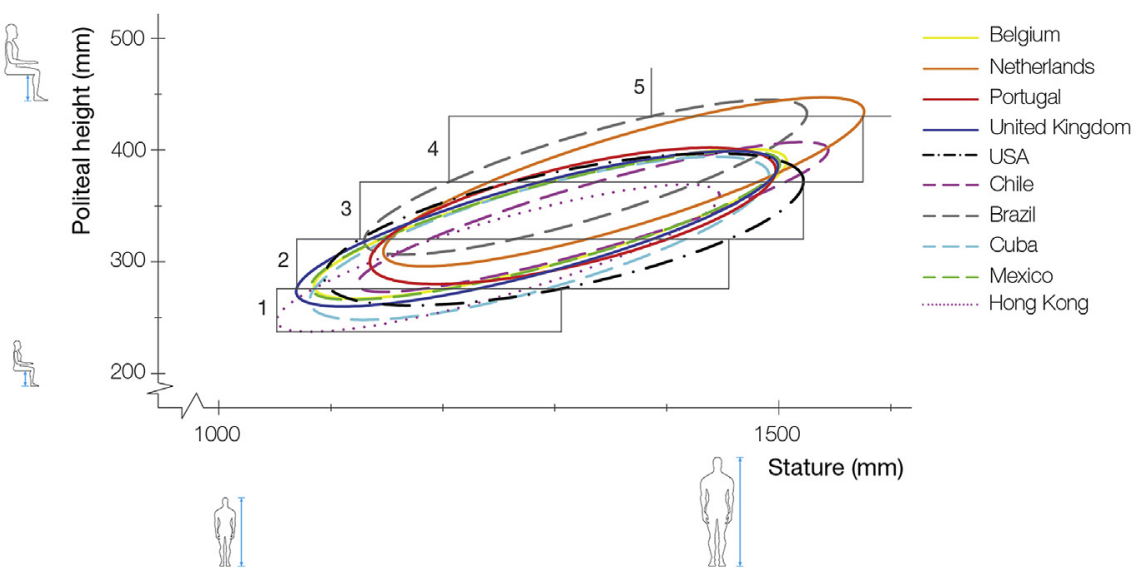

Fig. 17. Proposed sizes in accordance with Equation (1) and its coverage.

Equation (5) was used for the determination of the upper edge of the backrest (UEB) (see Fig. 20).

On the following chart, the relation between the popliteal height (PH) and shoulder height sitting (SHS) is presented. At each size the value of the adopted reference percentile is identified, P5 (lower edge corner of each rectangle), of the shoulder height sitting (SHS) range (Fig. 21).

On the P5 values the Equation (5) was applied to obtain the optimum values of the upper edge of the backrest (UEB) on the 5 sizes proposed.

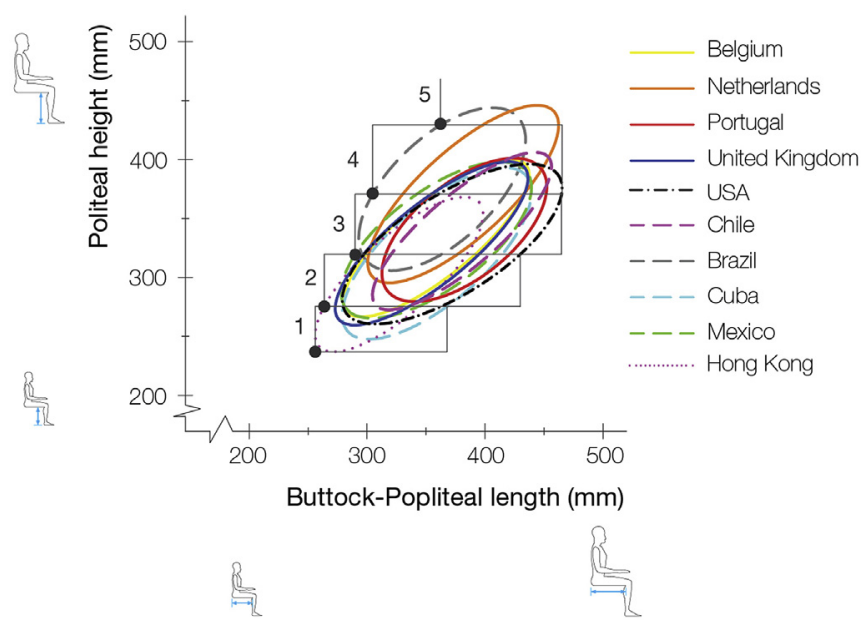

Fig. 18. - Representation of the 5 proposed sizes over a bivariate distribution of the popliteal height (PH) and buttock-popliteal length (BPL).
3.5. Calculation of the height of the $S$ point (SP) and the lower edge of the backrest (LEB)

In the calculation of the S point (SP), to obtain the value of the adopted reference percentile, $\mathrm{P} 50$, the stature range corresponding to each size proposed was considered (Fig. 17). Once obtained this value for each size the Equation (6) was applied to achieve the optimum value of the $S$ point (SP) on the 5 sizes proposed.

In the calculation of the lower edge of the backrest (LEB), in

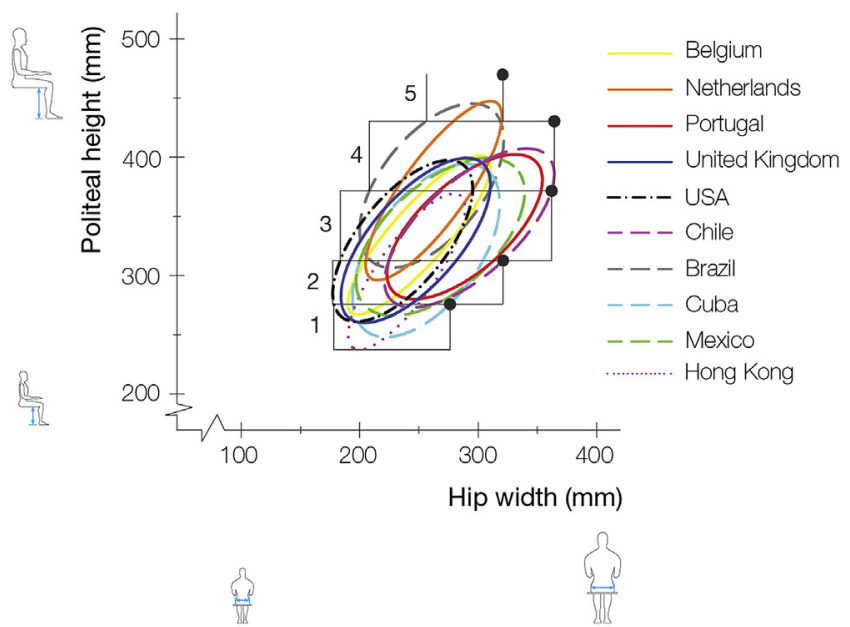

Fig. 19. - Representation of the 5 proposed sizes over a bivariate distribution of the popliteal height $(\mathrm{PH})$ and the hip width (HW) 


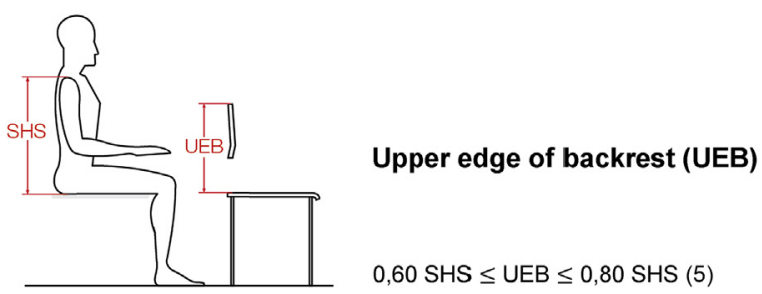

Fig. 20. Correlation between shoulder height sitting (SHS) with upper edge of backrest (UEB). Equation (5): Upper edge of backrest (UEB) sizing through the shoulder height sitting (SHS).

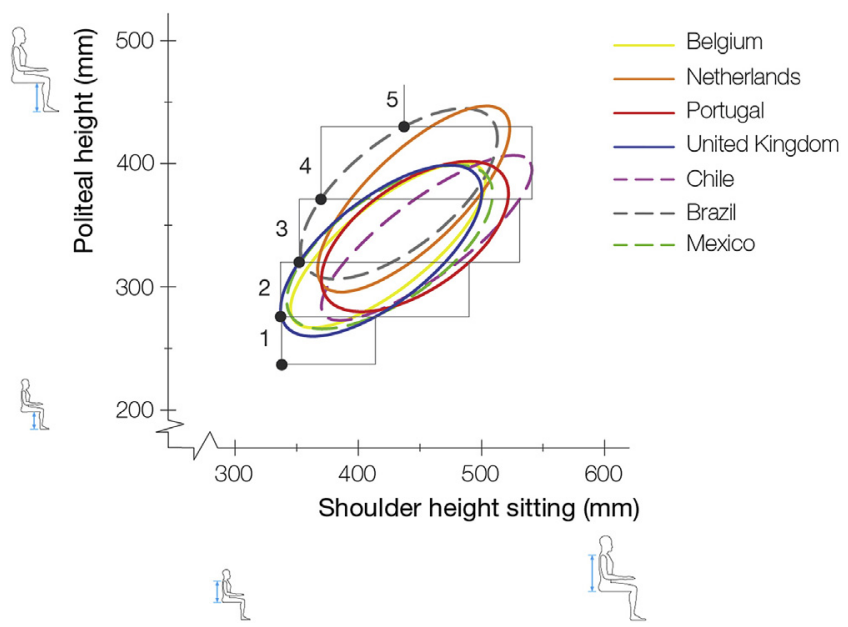

Fig. 21. Representation of the 5 proposed sizes over a bivariate distribution of the popliteal height (PH) and shoulder height sitting (SHS).

order to obtain the value of the reference percentile, P95, the stature range corresponding to each size proposed was considered (Fig. 17). Once obtained this value for each size it was applied to the Equation (7) to achieve the optimum value of the lower edge of the backrest (LEB) on the 5 sizes proposed.

\subsection{Calculation of the seat to desk clearance (SDC)}

For the calculation of the seat to desk clearance (SDC), the Equation (8) that has as a reference the thigh thickness (TT) is considered. The chart that relates the popliteal height $(\mathrm{PH})$ and the thigh thickness (TT) allows identifying in each size the value of the adopted reference percentile, P95 (top right corner of each rectangle), for the thigh thickness (TT) range (Fig. 22).

Over the P95 values, is applied the Equation (8) is applied to obtain the optimum value of the seat to desk clearance (SDC) on the 5 sizes proposed.

\subsection{Calculation of the desk height (DH)}

For the calculation of the desk height (DH), the Equation (9) that takes into account the seat height ( $\mathrm{SH}$ ) is considered, as well as the seat to desk clearance (SDC) which is obtained by Equation (8), and the table thickness $(\mathrm{T})$.

\section{Results}

The calculations performed for each dimension indicated that 5 sizes were needed to accommodate the population studied. For each of these sizes, the recommended dimensions are described in the following table (Table 7). Although all calculations have been
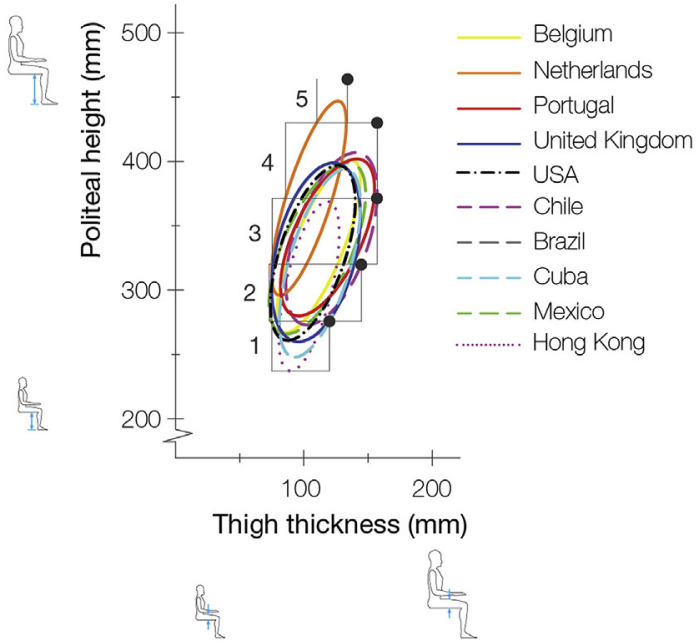

Fig. 22. - Representation of the 5 proposed sizes over a bivariate distribution of the popliteal height (PH) and thigh thickness (TT).

made based on the popliteal height ( $\mathrm{PH})$, it is given for each size the corresponding stature range only as a secondary reference.

\section{Discussion}

From this study, a set of universal measures can be defined for school furniture, chair and desk set, for children from 6 to 10 years old. With the popliteal height (PH) as a prescription measurement it is possible to have all the children properly seated without overlapping sizes (Fig. 17). It is also noted that popliteal height (PH) corresponds only to one chair and desk size, which does not happen with stature.

It is recommended that these sizes are used in adjustable chairs and desks, adapting to the growth of children during primary education, which lasts no less than four years. In this sense, this method has clear advantages both for schools and industry.

Capítulo 1 The schools only need to purchase an adjustable chair, rather than several chairs of different sizes (Table 8) to accommodate their students. With adjustable chairs when children move from classroom to classroom they do not need to carry the chair with them, only needing to adjust the chair in the other classroom for their size. This reverses the current trend in schools, where in the same classroom is commonly used a single chair size which is clearly insufficient. Children in the same class and of the same age have different popliteal heights $(\mathrm{PH})$ requiring different sized chairs to accommodate them properly. With an adjustable chair that problem is solved.

Capítulo 3 For the application of this system in school it is recommended the measurement of the popliteal height (PH) twice per year (Molenbroek et al., 2003). A easily method to put in practice is the 'Peter lower leg meter', as described in Castellucci et al. (2015). With this measurement teachers just have to see what the corresponding size is and adjust the chair if necessary.

For companies producing adjustable chairs this allows not only the reduction of stocks and the correspondent occupied space, but also an economically viable production (Fig. 23).

It should also be highlighted the need to further develop this research through the collection of more systematic anthropometric information, namely a wider range of countries and more current information, due to the secular tendency of growth, which may lead to changes in the optimal values of the system of proposed sizes. It would be also interesting to extend the system to accommodate 
Table 7

Proposal for a universal system of sizes for school chair and desk set for children from 6 to 10 years old.

\begin{tabular}{|c|c|c|c|c|c|c|}
\hline & \multirow[t]{2}{*}{ Furniture dimension } & \multicolumn{5}{|l|}{ Set size } \\
\hline & & 1 & 2 & 3 & 4 & 5 \\
\hline \multirow[t]{2}{*}{$\mathrm{PH}$} & Popliteal Height (Range) & $237-275$ & $275-320$ & $320-371$ & $371-430$ & $430-497$ \\
\hline & Stature range & $1051-1306$ & $1069-1455$ & $1126-1522$ & $1205-1575$ & $1386-1576$ \\
\hline $\mathrm{SH}$ & Seat height & 256 & 295 & 339 & 390 & 448 \\
\hline SD & Seat depth (max.) & 243 & 251 & 276 & 290 & 345 \\
\hline SW & Seat width (min.) & 276 & 321 & 362 & 364 & 364 \\
\hline UEB & Upper edge of backrest (max.) & 270 & 270 & 282 & 296 & 350 \\
\hline SP & S Point & 135.5 & 145 & 152 & 160 & 170 \\
\hline LEB & Lower edge of backrest (min.) & 76 & 84 & 88 & 91 & 91 \\
\hline ELAM & Seat to desk clearance (min.) & 140 & 165 & 177 & 177 & 177 \\
\hline $\mathrm{DH}$ & Desk height & 461 & 525 & 581 & 632 & 690 \\
\hline
\end{tabular}

Table 8

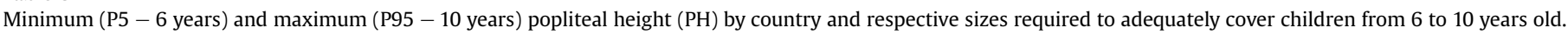

\begin{tabular}{|c|c|c|c|}
\hline \multirow{2}{*}{$\begin{array}{r}\text { Country } \\
\text { BELGIUM }\end{array}$} & \multicolumn{2}{|c|}{ Popliteal height $(\mathrm{PH})$} & \multirow{2}{*}{$\begin{array}{l}\text { Required Set } \\
\text { Sizes } \\
1 ; 2 ; 3\end{array}$} \\
\hline & 267 & 401 & \\
\hline BRAZIL & \multicolumn{2}{|c|}{307} & $1 ; 2 ; 3 ; 4$ \\
\hline CHILE & 273 & 407 & $1 ; 2 ; 3 ; 4$ \\
\hline CUBA & 248 & 394 & $1 ; 2 ; 3 ; 4$ \\
\hline HONG KONG & 237 & 69 & $2 ; 3 ; 4 ; 5$ \\
\hline MEXICO & 266 & 399 & $1 ; 2 ; 3 ; 4$ \\
\hline NETHERLANDS & 296 & 447 & $1 ; 2 ; 3$ \\
\hline \multirow{2}{*}{$\begin{array}{r}\text { PORTUGAL } \\
\text { UNITED KINGDOM }\end{array}$} & 280 & 402 & $1 ; 2 ; 3 ; 4$ \\
\hline & 260 & 399 & $2 ; 3 ; 4 ; 5$ \\
\hline \multirow[t]{2}{*}{ U.S.A } & 261 & 397 & $2 ; 3 ; 4$ \\
\hline & a 5 - 6 years & P95 - 10 years & \\
\hline
\end{tabular}

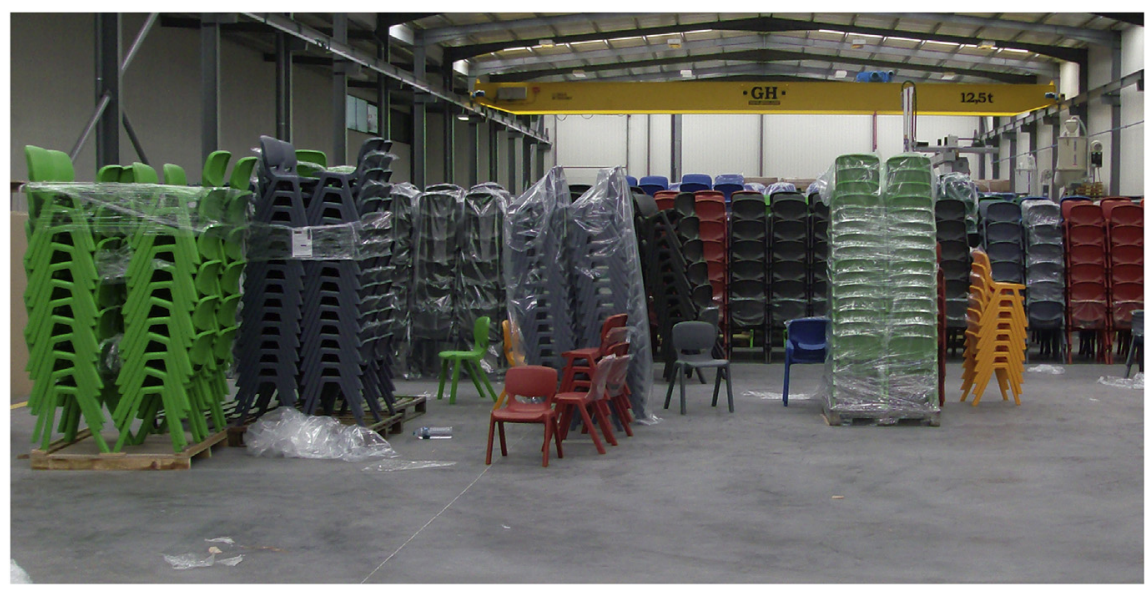

Fig. 23. Stock of Ergos chair of different sizes in NAUTILUS SA. Company.

children from 4 to 20 years old.

Despite the existence of programs like People Size, which allow the approximation of anthropometric measurements, they use the stature along with ratios to determine the other anthropometric measures. As demonstrated in section 2.2 this technique is not very reliable, because people with same stature have different 
dimensions for the same anthropometric variables, so this approach was not used.

\section{Conclusion}

For companies wishing to compete in international markets, their product ranges must be competitive and fit the market they are being designed for.

In the school furniture industry, the chair and desk sets have a major role to ensure comfort within the classroom. From the age of 6 , all children spend much of their time in this space. If the furniture they use does not correspond with their anthropometry, it will lead to discomfort, physiological problems, the adoption of bad postures and influence learning outcomes, as a child who is uncomfortable or in pain, will become distracted (Castellucci et al., 2014b; Gonçalves, 2012; Moro, 2005; Panagiotopoulou et al., 2004; Reis, 2003; Reis et al., 2005). However, no Standards have been developed which consider these issues.

Anthropometric measures which take into account recent changes in child anthropometry and a set of methods to help designers and manufacturers produce chairs and desks compatible with the size of children and the activities they undertake in schools are essential if children are to achieve successful learning outcomes, be comfortable in schools and graduate from them with good posture and healthy bodies.

To ensure the perfect relation between the ergonomic needs and productive reality, it is necessary to guarantee the reliability of this type of study, taking into account the production capacity and the needs of a market that intends to be increasingly global. When looking for internationalization, it becomes necessary to respond to different regulatory constraints, which has been an obstacle. It is in the genesis of the conception of universal products that a change should begin to emerge, in the adaptation of the product design to the realities and specificities of each country, based on just one universal Standard.

In conclusion, with the development of this study, it was possible to find a normative model able to support the work of conception and design of the school chair and desk set. It is now possible to conceive chairs and desks for an international global market, based on specific ergonomic criteria, covering in particular children from 6 to 10 years old of each country.

\section{References}

AAVV, 2013. Crescimento, desenvolvimento e maturação. Fundação Vale, Unesco, Brasília.

Afzan, Z.Z., Hadi, S.A., Shamsul, B.T., Zailina, H., Nada, I., Rahmah, A.R.S., 2012 Mismatch between school furniture and anthropometric measures among primary school children in Mersing, Johor, Malaysia. In: Network of Ergonomics Societies Conference (SEANES), 2012 Southeast Asian, pp. 1-5.

Agha, S.R., 2010. School furniture match to students' anthropometry in the Gaza Strip. Ergonomics 53, 344-354.

Canadian Institute of Child Health, 2007. Child Anthropometry: a Literature Scan of National and International Publications. Transport Canada, Ottawa, ON, p. 83.

Castellucci, H.I., Arezes, P.M., Molenbroek, J.F.M., 2014a. Applied anthropometrics in school furniture design: which criteria should be used for standardization? In: Ahram, T., Karwowski, W., Marek, T. (Eds.), 5th International Conference on Applied Human Factors and Ergonomics, Kraków, Poland.

Castellucci, H.I., Arezes, P.M., Molenbroek, J.F.M., 2014b. Applying different equations to evaluate the level of mismatch between students and school furniture. Appl. Ergon. 45, 1123-1132.

Castellucci, H.I., Arezes, P.M., Molenbroek, J.F.M., 2015. Analysis of the most relevant anthropometric dimensions for school furniture selection based on a study with students from one Chilean region. Appl. Ergon. 46 (Part A), 201-211.

Castellucci, H.I., Arezes, P.M., Viviani, C.A., 2010a. Mismatch between classroom furniture and anthropometric measures in Chilean schools. Appl. Ergon. 41, 563-568.

Castellucci, H.I., Gonçalves, M.A., Arezes, P.M., 2010b. Ergonomic design of school furniture: challenges for the Portuguese schools. In: Karwowski, W., Salvendy, G. (Eds.), 3rd International Conference on Applied Human Factors and Ergonomics Conference. USA Publishing, Miami, FL, pp. 197-202.
Center on International Education Benchmarking, 2014. Hong Kong Instructional Systems. National Center on Education and the Economy, Washington.

Dianat, I., Karimi, M.A., Asl Hashemi, A., Bahrampour, S., 2013. Classroom furniture and anthropometric characteristics of Iranian high school students: proposed dimensions based on anthropometric data. Appl. Ergon. 44, 101-108.

Domljan, D., Grbac, I., Hadina, J., 2008. Classroom furniture design-correlation of pupil and chair dimensions. Coll. Antropol. 32, 257-265.

Domljan, D., Vlaovic, Z., Grbac, I., 2010. Pupils' working postures in primary school classrooms. Period. Biol. 112, 39-45.

Eurydice, 2014. Structure of European Education Systems 2014/15. European Commission, Brussels.

Evans, W.A., Courtney, A.J., Fok, K.F., 1988. The design of school furniture for Hong Kong schoolchildren: an anthropometric case study. Appl. Ergon. 19, 122-134.

Fryar, C.D., Gu, Q., Ogden, C.L., 2012. Anthropometric Reference Data for Children and Adults: United States, 2007-2010. Vital and health statistics. Series 11, Data from the national health survey, 48.

Fuentes, A.M., 2001. Dimensiones antropométricas de población escolar Cubana de 6 a 18 años. In: Chaurand, R.Á., Prado-León, L.R., Muñoz, E.L.G. (Eds.), Dimensiones antropométricas de población Latinoamericana: México, Cuba, Colombia, Chile, 1 ed. Universidad de Guadalajara, Centro Universitario de Arte, Arquitectura y Diseño, Guadalajara, pp. 145-155.

Gonçalves, M.A., 2012. Análise das condições ergonómicas das salas de aula do primeiro ciclo do ensino básico, Engenharia Industrial e de Sistemas. Universidade do Minho, Braga, p. 197.

Gouvali, M.K., Boudolos, K., 2006. Match between school furniture dimensions and children's anthropometry. Appl. Ergon. 37, 765-773.

Guat-Lin, E.T., 1984. Anthropometric Data and its Use for Educational Building and Furniture Design. Unesco - Regional Office for Education in Asia and the Pacific, Bangkok.

Hafezi, R., Mirmohammadi, S.J., Mehrparvar, A.H., Akbari, H., Akbari, H., 2010. An analysis of anthropometric data on Iranian primary school children. Iran. J. Public Health 39, 78-86.

Iida, I., 2005. Ergonomia: Projeto e Produção, second ed. Edgard Blücher, São Paulo.

Malina, R.M., Hamil, P.V.V., Lemeshow, S., 1973. Selected Body Measurements of Children 6-11 Years, United States. Vital and health statistics. Series 11, Data from the national health survey, 48.

Ministério da Saúde do Brasil, 2002. Saúde da Criança: acompanhamento do crescimento e desenvolvimento infantil. Ministério da Saúde, Brasília.

Mokdad, M., Al-Ansari, M., 2009. Anthropometrics for the design of Bahraini school furniture. Int. J. Ind. Ergon. 39, 728-735.

Molenbroek, J., Kroon-Ramaekers, Y., Snijders, C., 2003. Revision of the design of a standard for the dimensions of school furniture. Ergonomics 46, 681-694.

Moro, A.R.P., 2005. Ergonomia da sala de aula: constrangimentos posturais impostos pelo mobiliário escolar. Rev. Digit. 10, 1-6.

Motmans, R., Ceriez, E., 2005. Body Dimensions of the Belgian Population, Leuven.

Newman, B.M., Newman, P.R., 2012. Development through Life: a Psychosocial Approach, 11th ed. Cengage Learning, United States of America, Wadsworth.

Nowak, E., 2000. Atlas Antropometryczny Populacji Polskiej - dane do Projektowania. Instytut Wzornictwa Przemysłowego, Warszawa.

Ortiz, M.R.R., 2008. Tablas Antropométricas Infantiles. Universidad Nacional de Colombia. Facultad de Artes, Bogotá.

Panagiotopoulou, G., Christoulas, K., Papanckolaou, A., Mandroukas, K., 2004 Classroom furniture dimensions and anthropometric measures in primary school. Appl. Ergon. 35, 121-128.

Panero, J., Zelnik, P., 1996. Las Dimensiones Humanas En Los Espacios Interiores: Estándares Antropométricos, 7 ed. Editorial Gustavo Gili, Barcelona.

Parcells, C., Stommel, M., Hubbard, R.P., 1999. Mismatch of classroom furniture and student body dimensions: empirical findings and health implications. J. Adolesc. Health 24, 265-273.

Paschoarelli, L.C., 1997. O Posto de trabalho. Carteira Escolar como Objeto de Desenvolvimento da Educação Infantil: uma Contribuição do Design e da Ergonomia. Faculdade de Arquitetura, Artes e Comunicação. Universidade Estadual Paulista, Bauru, p. 136.

Pequini, S.M., 2005. Ergonomia Aplicada ao Design de Produtos: Um estudo de caso sobre o desgin de bicicletas. Faculdade de Arquitetura e Urbanismo. Universidade de São Paulo, São Paulo.

Pheasant, S., 2003. Bodyspace: Anthropometric, Ergonomics and the Design of Work, second ed. Taylor \& Francis, London; Philadelphia.

Poston, A., 2002. Index of Non-government Standards on Human Engineering Design Criteria and Program Requirements/Guidelines Version 3. Department of Defense, Human Factors Engineering Technical Advisory Group, Human Factors Standardization., Reston, VA, p. 41.

Prado-León, L.R., Avila-Chaurand, R.o., González-Muñoz, E.L., 2001. Anthropometric study of Mexican primary school children. Appl. Ergon. 32, 339-345.

Reis, P.F., 2003. Estudo da Interface Aluno-Mobiliário: A Questão Antropométrica e Biomecânica da Postura Sentada. Universidade Federal de Santa Catarina, Florianópolis, p. 109.

Reis, P.F., Reis, D.C.d., Moro, A.R.P., 2005. Mobiliário Escolar: Antropometria e Ergonomia da Postura Sentada. XI Congresso Brasileiro de Biomecânica. CBB, São João, PB.

Ribeiro, L.F., 2012. Design de Mobiliário Adaptável ao Crescimento da Criança. Faculdade de Engenharia. Univ. do Porto, Porto, p. 126.

Silva, J.C.P., Paschoarelli, L.C., Spinoza, R.M.O., 1995. Interface Antropométrica Digital: Público Infantil; da Pré-escola ao Ensino Fundamental. Laboratório de Ergonomia e Interfaces, Faculdade de Arquitetura, Artes e Comunicação. 
Universidade Estadual Paulista, Bauru.

Steenbekkers, L.P.A., Molenbroek, J.F.M., Dirken, J.M., 1993. Dutch Children. Delft University of Technology, Delft.

Troussier, B., 1999. Comparative study of two different kinds of school furniture among children. Ergonomics 42, 516-526.
UNESCO, 2012. International Standard Classification of Education - ISCED 2011. UNESCO Institute for Statistics, Montreal.

UNESCO International Bureau of Education, 2010. World Data on Education Seventh Edition 2010/11. UNESCO, Genebra. 